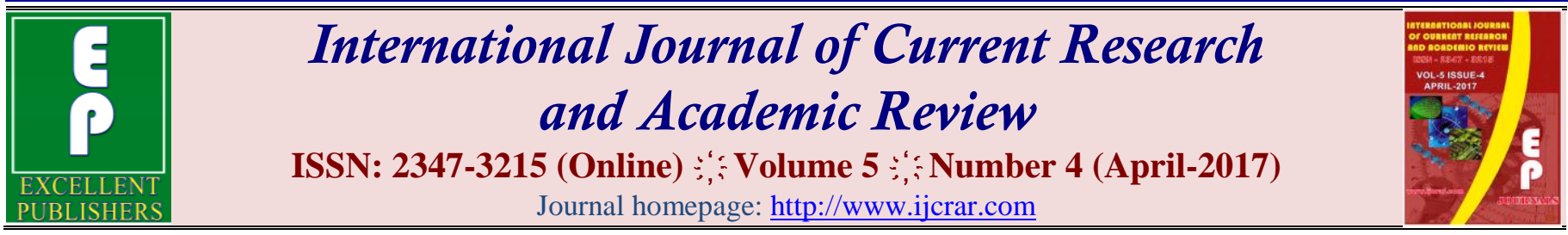

doi: https://doi.org/10.20546/ijcrar.2017.504.004

\title{
The Change of Local Food Consumption Pattern from Sago to Rice (Case Study of Social Change in Central Maluku)
}

\author{
August E. Pattiselanno* and Junianita F. Sopamena \\ Department of Agribusiness, Faculty of Agriculture, Pattimura University, Ambon, Indonesia \\ *Corresponding author
}

\begin{abstract}
Sago was the alternative main food besides rice for Indonesian people in Maluku. Food consumption pattern of Central Maluku citizens had shifted from sago to rice. This research was aimed to analyze the change of local food consumption pattern from sago to rice by considering this change as a social change. Primary data were obtained from interview. Questionnaire was given to 200 respondents who were randomly selected from four district samples. Deep interview was conducted with key informant in each district to support the data. Result of research indicated that the change of local food consumption pattern could be considered as social change. The change of consumption pattern was differentiated into several types, such as: consumption pattern change from Sago to Rice with Rice-dominant was shown by 106 respondents (53\%); consumption pattern change from Sago to Rice with Sago-dominant was admitted by 52 respondents (26\%); and consumption pattern change into Sago and Rice at same quantity was displayed by 42 respondents $(21 \%)$.
\end{abstract}

\section{Article Info}

Accepted: 28 March 2017

Available Online: 20 April 2017

\section{Keywords}

Social Change, Consumption Pattern, Sago, Rice.

\section{Introduction}

\section{Background}

Maluku had been known as consuming sago as main food. Being source of energy, sago was equivalent with rice, corn, cassava, potato, and wheat flour. Sago could be processed into potential food because it was containing high level of carbohydrate, precisely 84.7 grams per 100 grams material. However, sago was lacking of protein. The protein level of sago flour was only $0.7 \mathrm{~g} / 100 \mathrm{~g}$, and it was lower than flours made from rice, corn and wheat. Vitamin and mineral contents of sago were also lower than other food materials. Because nutrient potential of sago was not as complete and good as other food materials, thus, sago must be consumed together or in mixture with other material with better nutrient value. A diversification concept in consumption pattern had been applied by traditional community in Maluku, including those living in Central Maluku. They combined sago with fish (being source of protein) and also with vegetables (being source of vitamin, mineral, anti-oxidant, and food fiber).

In other hand, the government had published President Decree No.22/2009 about the Policy of Acceleration of Food Consumption Diversity based on Local Resource. This Decree attempted to produce food diversity through integral and systematical ways. The Decree was followed by the Decree of Agriculture Minister No.43/2009 about the Initiative of Acceleration of Food Consumption Diversity (P2KP) based on Local Resource as the guidance of implementation. 
Fact on the field showed that during New Order, rice was the main food of the community and it was provided by the government. However, community started to consume rice instead of sago as main food.

\section{Problem Formulation}

National Survey on Socioeconomy (Susenas) had found that $108.56 \mathrm{~kg}$ of $139 \mathrm{~kg}$ total consumption of carbohydrate per capita per year in Maluku was achieved through various ways. The order was $78 \%$ derived from rice, $18 \%$ from tubers, and $4 \%$ from sago (BPS of Maluku Province, 2011). Therefore, the demand for rice in Maluku with the population of 1,611,140 heads was reaching $174,905,000$ tons per year, whereas the production of rice in Maluku was only 85,914,000 tons per year. The consumption of rice in Maluku was almost 120,000 tons per year but the production of rice at the local only attained 79,000 tons per year. Although rice production in Maluku did not meet consumption demand, but the availability of rice stock in Maluku was still safe because Bulog provided annual supply for more than 120,000 tons and some distributors also gave supply of the super quality rices (BPS of Maluku Province, 2014). The problem was not in the availability of rice stock, but in the too much dependency of the community on rice which could marginalize local food.

The food consumption pattern of community had been changed from local food (sago) to rice. It was what so called as social change. It aligned with Suryanegara, Ellen, Suprajaka, and Irmadi Nahib (2015) who studied social change in Bajo Community who lived permanently at their place. It was found that Bajo Community experienced a change in their behavioral pattern, social interaction, community value, social organization, composition of community, and social layer in the community. Mulyadi (2015) explained that the change was going toward progressive direction which must be beneficial to the community, at least by increasing social welfare of the community in Makassar City.

However, it did not close chances of cutback which led to the unexpected social condition. In contrast, Ofuoko and Albert (2014) inferred from Nigeria contex that young, educated and wealthy farmers were not easy to abandon their traditional farming practices. Tractor, offfarm activities, and also farming size, were related closely with traditional farming practices. Baite (2014) had reported that Baites Tribe in India had rejected the persuasion of assimilation from bigger community, and kept continuing their primordial culture by defending their unique identity, including the utilization of local food.

By considering this overview as background, problem could then be formulated: Could the change of local food consumption pattern from sago to rice be perceived as social change?

\section{Research Objective}

This research was aimed to analyze social change through the change of local food consumption pattern from sago to rice.

\section{Research Methodology}

\section{Time, Location of Research, and Sampling Method}

Research was conducted in Central Maluku Regency, precisely at four village samples that were purposively selected. These villages were: Messa Village (TNS District), Yafila Village (Amahai District), Aboru Vilage (Haruku Island District), and Ihamahu Village (East Saparua District).

The selection of sample villages was based on the activity of community dominated by local food processing (sago and tubers) as income source. Research was done in four months, from June to September 2016. From each village, 50 respondents were selected in simple random method. Total of respondents would then be 200 persons. Key informants were also selected from each village on demand to explain the answer given by respondents.

\section{Method of Data Collection and Data Analysis}

Data collection technique involved questionnaire given to respondents (Babbie, 2004; 184) to collect primary data, and deep interview with key informants (Debus and Noveli, 1996). The result of this technique was supported by participative observation (Denzim dan Lincoln, 1994; Babbie, 2004), meaning that the author was engaged directly into daily life of the community that the author observed by hearing and discerning what had been said and done by research subject.

Data analysis involved Simple Tabulation to describe the condition and characteristic of social change at research location. The collected data were processed and presented into table and diagram to facilitate the analysis. 


\section{Results and Discussion}

\section{Consumption Pattern Change}

Consumption pattern in Central Maluku was changed since 1970s. The reason was the changing economical level (income) of the household. In other side, there was a possibility that the consumption pattern of Central Maluku community was previously dominated by sago, but the community suffered from controversy when rice began to dominate.

As shown by 200 respondents who were considered representative, it could be said that Central Maluku had experienced consumption pattern change as indicated in Table 1.

From the table above, it was known that there were three identifications of consumption pattern change if compared with theory of consumption pattern.

Consumption pattern change "from sago to rice with sago-dominant", consumption pattern and eating habit were generally influenced by some factors, including education, nutrient awareness, prohibition or taboo, available food material, economical consideration, and natural environment. Sago was a plant that was easily found in nature and also that could be processed into consumable food material. Most respondents used to consume sago as main food. Consuming sago did not need high cost.

Consumption pattern change "from sago to rice with rice-dominant", this change was caused by the degree of activity of respondents. Some respondents had heavy work, and rice was consumed to give extra energy to support their work activity. Other respondents showed a consistency of consuming rice as their main food.

Consumption pattern change "into sago and rice at same quantity", consumption pattern of respondents was still relying on certain quantity of rice and sago. Such pattern had been persistent, and the quantity was made similar.

\section{Social Change in the Context of Consumption Pattern Change}

Social change in the context of consumption pattern change could be explained from some factors that influenced social change (Etzioni and Etzioni, 1973; Soerjono Soekanto, 1987; Harper, 1989; Salim, 2014). It was described as following:

\section{Fluctuation of Population}

Community migrated from rural to urban regions, or just moved to other regions. This migration compelled a certain change to migrant community. Field observation had found that from year to year, Central Maluku community experienced a change within their population growth, and the trend went upward. But, it forced community to change their consumption pattern. Singh and Singh (2016) had reported that the increase of population in Punjab Village had forced, in consequence, some farming laborers to be the victim of social, political and economical exploitations, and also to suffer from discriminative treatments due to the very low income and the incapacity to fulfill basic necessities.

\section{New Inventions}

Central Maluku community did not have innovation because tradition was still persistent. In relation with social process, the community was open to new culture, and by the times, this new culture was used and then claimed as their tradition. Sago and tubers had been known along ago as main food. But, when rice was sold at affordable price, the community changed their consumption pattern. The culture of community outside Central Maluku might trigger this kind of change. Patill (2012) explained that education is seen as a major vector in society, but that it is largely allocated a conservative role, since its main function is in the socialization of the young and the maintenance of the social order. Parera (2014) discovered that the impact of development in Sri Lanka had increased the income of non-poor community who was at same time affected by various governmental programs.

\section{Contradiction}

Eating pattern was important priority of respondents because this pattern was closely related with their job. Most respondents had job being farmers and fishers, and therefore, huge extra energy was needed. The source of energy came from food the respondents consumed. Eating pattern of Central Maluku community was previously dominated by sago, but the domination was then defeated by rice. It triggered a contradiction among few persons (the elders) because it was perceived that rice was not the main food of Central Maluku community. Therefore, some persons still consumed sago and tubers as main foods. Different result was given by Lumintang (2015) who said that a large volume of development had changed the habit of the community in 
Tara-Tara I Village, North Sulawesi, when must deal with problems and challenges. Indeed, problems and challenges were mostly resolved with a deliberation for consensus by giving attention to the priority scale of development.

\section{Causes from Physical and Natural Environments around Human}

Sago in Central Maluku was not a commodity and also not cultivated. When sago was consumed, some sago trees must be cut. The increase of population rate and the exploitative development had converted sago land into residence and office complex. This change indeed reduced sago production which helped increasing the consumption rate of the rice which replaced sago as alternative food. Katrak (2014) stated that community in
India villages failed to develop because it lacked of structures and infrastructures that should be provided by the government.

\section{The Effect of Other Community Culture}

The change of consumption pattern in Central Maluku community was also caused by more acknowledgment of people to rice existence. Rice was a national food, and started to become the main food of every community in Indonesia. Rice was the principal food of Javanese ethnic but it dominated already food consumption pattern in Central Maluku community. Saini (2016) asserted that the indigenous people in southern part of India experienced a similar change after being subjected to external intervension.

Table.1 Consumption pattern change in Central Maluku

\begin{tabular}{|c|c|c|c|c|}
\hline No & $\begin{array}{c}\text { The Identification of } \\
\text { Consumption Pattern } \\
\text { Change }\end{array}$ & $\begin{array}{l}\text { Number of } \\
\text { Respondents } \\
\text { (Person) }\end{array}$ & $\begin{array}{l}\text { Number of } \\
\text { Respondents } \\
\text { (Person) }\end{array}$ & Reason \\
\hline \multirow[t]{8}{*}{1} & \multirow[t]{8}{*}{$\begin{array}{l}\text { From Sago to Rice with } \\
\text { Rice-Dominant }\end{array}$} & \multirow[t]{8}{*}{$106(53 \%)$} & 53 & $\begin{array}{l}\text { Household income was } \\
\text { adequate. }\end{array}$ \\
\hline & & & 40 & Rice was satiate. \\
\hline & & & 47 & Rice was available. \\
\hline & & & 20 & Rice gave energy. \\
\hline & & & 46 & Kids loved consuming rice. \\
\hline & & & 13 & $\begin{array}{l}\text { Rice was considered as main } \\
\text { food. }\end{array}$ \\
\hline & & & 6 & Rice gave health. \\
\hline & & & 6 & $\begin{array}{l}\text { Rice could indicate prestige } \\
\text { of household. }\end{array}$ \\
\hline \multirow[t]{7}{*}{2} & \multirow{7}{*}{$\begin{array}{l}\text { From Sago to Rice with } \\
\text { Sago-Dominant }\end{array}$} & \multirow[t]{7}{*}{$52(26 \%)$} & 20 & Income was not certain. \\
\hline & & & 13 & Rice was expensive. \\
\hline & & & 6 & $\begin{array}{l}\text { Consuming sago was } \\
\text { cheaper. }\end{array}$ \\
\hline & & & 6 & $\begin{array}{l}\text { It helped eliminating thirst at } \\
\text { work. }\end{array}$ \\
\hline & & & 13 & $\begin{array}{l}\text { Maluku people worked as } \\
\text { sago farmers. }\end{array}$ \\
\hline & & & 13 & $\begin{array}{l}\text { People usually brought sago } \\
\text { at home for food reserve. }\end{array}$ \\
\hline & & & 6 & $\begin{array}{l}\text { Sago was traditional main } \\
\text { food. }\end{array}$ \\
\hline \multirow[t]{3}{*}{3} & \multirow[t]{2}{*}{$\begin{array}{l}\text { Into Sago and Rice at } \\
\text { same quantity }\end{array}$} & \multirow[t]{2}{*}{$42(21 \%)$} & 13 & $\begin{array}{l}\text { Sago was ancestral heritage } \\
\text { which must be consumed. }\end{array}$ \\
\hline & & & 19 & $\begin{array}{l}\text { Rice was prestigious, and } \\
\text { thus, rice and sago was kept } \\
\text { in balance. }\end{array}$ \\
\hline & TOTAL & 200 & & \\
\hline
\end{tabular}


Table.2 Social Change in The Context of Consumption Pattern Change

\begin{tabular}{|c|c|c|c|c|}
\hline No & $\begin{array}{l}\text { Social Change in the Consumption } \\
\text { Pattern Change }\end{array}$ & Opinions of Respondents & $\begin{array}{c}\text { Number of } \\
\text { Respondents }\end{array}$ & $\begin{array}{c}\text { Change Indicator } \\
\text { (Etzioni and Atzioni, 1973; } \\
\text { Soekanto, 1987; Harper, } \\
\text { 1989; Salim, 2014) } \\
\end{array}$ \\
\hline 1 & $\begin{array}{l}\text { The change in food meaning as group } \\
\text { identity }\end{array}$ & $\begin{array}{l}\text { Consumption pattern change did not happen } \\
\text { because sago was still preserved as main food. }\end{array}$ & 7 & $\begin{array}{l}\text { Causes from Physical and } \\
\text { Natural Environments }\end{array}$ \\
\hline \multirow[t]{2}{*}{2} & \multirow[t]{2}{*}{$\begin{array}{l}\text { The change in food meaning as } \\
\text { ethnical superiority }\end{array}$} & $\begin{array}{l}\text { Rice was known as important food that satisfied } \\
\text { household demand for food. }\end{array}$ & 7 & $\begin{array}{l}\text { The Effect of Other Community } \\
\text { Culture }\end{array}$ \\
\hline & & $\begin{array}{l}\text { Consuming sago would maintain local identity, } \\
\text { while consuming rice was to represent national } \\
\text { food. }\end{array}$ & 7 & $\begin{array}{l}\text { Causes from Physical and } \\
\text { Natural Environments }\end{array}$ \\
\hline \multirow[t]{2}{*}{3} & \multirow[t]{2}{*}{ The change in consumption pattern } & $\begin{array}{l}\text { The change from sago to rice was facilitated by } \\
\text { the increase of income, and supported by food } \\
\text { modernization, including fast-food. }\end{array}$ & 46 & New Inventions \\
\hline & & $\begin{array}{l}\text { Appetite was changed because the income was } \\
\text { increased, the rice was afforded at reasonable } \\
\text { price, and there was rice-for-poor program from } \\
\text { the government. }\end{array}$ & 13 & $\begin{array}{l}\text { The Effect of Other Community } \\
\text { Culture }\end{array}$ \\
\hline
\end{tabular}

Source: Result of Research (Processed, 2016) 
The change of consumption pattern could be elaborated in table 2 .

As shown by the table above, social change in the context of consumption pattern change would easily occur when economical /income level was adequate. With adequate income, consumption pattern was easily changed. There were opinions about social change if related with consumption pattern change, especially when it was compared with theory or definition of social change.

The change in food meaning as group identity. A certain dish that did not contain main food material was not complete food for the community who ate it. The consumed food would not be complete or might be unpleasant if it disregarded the presence of local food.

The change in food meaning as ethnical superiority. The development of community was gradual, and it aligned with theory of social evolution. The change of consumption pattern of main food from sago to rice was arranged and planned through governmental policies. Since New Order, rice was set up by the government as main food, and it was enforced through various intensification programs including transmigration program as a form of land width extensification for fieldrice. Similar trend also prevailed in Central Maluku.

The change in consumption pattern was also evident when people were satisfied only by consuming main food in greater quantity than others. It could be said that the consumed main food was producing energy and giving satisfaction from consuming it.

\section{Conclusion}

The change of main food consumption pattern was considered as social change. This change comprised of several categories. Consumption pattern change from Sago to Rice with Rice-dominant was shown by 106 respondents $(53 \%)$. Consumption pattern change from Sago to Rice with Sago-dominant was admitted by 52 respondents $(26 \%)$. Consumption pattern change into Sago and Rice at same quantity was displayed by 42 respondents $(21 \%)$.

Local food consumption pattern from sago to rice was changed for some reasons. There was a change in food meaning as group identity. The background of this change was the presence of causes from physical and natural environments. There was also a change in food meaning as ethnical superiority. The trigger of this change was the effect of other culture and the new inventions. Food consumption pattern might change because rice was recognized as main food material that could satiate the community.

\section{References}

Babbie, Earl. 2004. The Practice of Social Research Publisher: Belmont, CA: Thomson / Wadsworth.

Badan Pusat Statistik Provinsi Maluku. 2011. Survai Sosial Ekonomi Nasional. Ambon [ID]: BPS, Provinsi Maluku.

Badan Pusat Statistik Provinsi Maluku. 2014. Maluku Dalam Angka Tahun 2014. Ambon [ID]: BPS, Provinsi Maluku.

Baite, Chungkhosei. 2014. Socio-cultural Life of Transborder Tribes: A Case Study of the Baites. Social Change 44(1) 119-129, CSD 2014, SAGE Publications, Los Angeles, London, New Delhi, Singapore, Washington DC, DOI: 10.1177/0049085714536804

Debus, Mary and Novelli, Porter. 1996. Methodological Review: A Handbook for Excellence in Focus Group Research, Washington D.C: Academy for Educational Development.

Denzin dan Lincoln. 1994. Handbook of Qualitative Research Publisher: Thousand Oaks: Sage Publications.

Eizioni-Havley, Eva and Amitai Etzioni (Eds). 1973. Social Change Sources, Patterns, and Consequences. New York: Basic Books, Inc, Publishers.

Harper, Charles, L. 1989. Exploring Social Change, New Jersey : Prentice Hall, Englewood Cliffs.

Katrak, Homi. 2014. Socio-Economic Inequities and Household Sanitation in Rural India: A Comparative Analysis for Three States. Social Change, 44(3); 413-421, CSD 2014, SAGE Publications, Los Angeles, London, New Delhi, Singapore, Washington DC, DOI: 10.1177/0049085714536804

Kementerian Pertanian, R.I. 2015. Peraturan Presiden (Perpres) No. 22 Tahun 2009 tentang Kebijakan Percepatan Penganekaragaman Konsumsi Pangan Berbasis Sumberdaya Lokal. Laporan P2KP. Badan Ketahan Pangan - Kementan RI.

Lumintang, Juliana. 2015. Pengaruh Perubahan Sosial Terhadap Kemajuan Pembangunan Masyarakat Di Desa Tara-Tara I. E-J., "Acta Diurna” Volume IV. No.2. Tahun 2015.

Mulyadi, Mohammad. 2015. Perubahan Sosial Masyarakat Agraris Ke Masyarakat Industri Dalam 
Pembangunan Masyarakat Di Kecamatan Tamalate Kota Makassar. Jurnal Bina Praja, Volume 7 Nomor 4 Edisi, 311 - 322.

Ofuoko, Albert Ukaro and Carol, O., Albert. 2014. Social Change, 44(3) 401-411. CSD 2014, SAGE Publications, Los Angeles, London, New Delhi, Singapore, Washington DC, DOI: 10.1177/0049085714536804

Parera, Jayantha. 2014. Displacement-induced Impoverishment: The Role of a Sustainable Income Restoration and Improvement Strategy in Livelihood Rehabilitation in Sri Lanka. Social Change, 44(3): 333-354, CSD 2014, SAGE Publications, Los Angeles, London, New Delhi, Singapore, Washington DC, DOI: 10.1177/0049085714536804

Pattil, Namita, P. 2012. Role of Education in Social Change. Int. Edu. E-J., \{Quarterly\}, ISSN 22772456, Volume -I, Issue-II, Jan-Feb-Mar 2012.

Saini, Ajay. 2016. The Southern Nicobar Islands as Imaginative Geographies Social Change, 46(4): 495-

\section{How to cite this article:}

August E. Pattiselanno, Junianita F. Sopamena. 2017. The Change of Local Food Consumption Pattern from Sago to Rice (Case Study of Social Change in Central Maluku). Int.J.Curr.Res.Aca.Rev. 5(4), 17-23.

doi: https://doi.org/10.20546/ijcrar.2017.504.004
511, CSD 2014, SAGE Publications, Los Angeles, London, New Delhi, Singapore, Washington DC, DOI: $10.1177 / 0049085714536804$

Salim, Agus. 2014. Perubahan Sosial : Sketsa Teori dan Refleksi Metodologi Kasus Indonesia. Tiara Waca Yogya (cetakan kedua).

Singh, Gurmanpreet Singh and Kamaljit Singh. 2016. Employment Patterns among Agricultural Labourers in Rural Punjab. Social Change, 46(3): 409-427, CSD 2014, SAGE Publications, Los Angeles, London, New Delhi, Singapore, Washington DC, DOI: $10.1177 / 0049085714536804$

Soerjono, Soekanto. 1987. Sosiologi Pedesaan., Bina Aksara Jakarta.

Suryanegara, Ellen, Suprajaka, dan Irmadi Nahib. 2015. Perubahan Sosial Pada Kehidupan Suku Bajo: Studi Kasus Di Kepulauan Wakatobi, Sulawesi Tenggara., Majalah Globe, Volume 17 No. 1Juni 2015: 067 078. 